\title{
The Ideology and Politics of Iowa Common School Reform, 1854-1860
}

\section{CARROLL ENGELHARDT}

PIONEER HISTORIAN of Iowa education Clarence Ray Aurner characterized the period after 1854 as an "educational awakening" achieved by Iowa educational leaders. Their demands and agitation brought about the appointment of a commission on school law revision in 1856 and the enactment of a fundamental school law in 1858. Subsequent historians of Iowa education have followed Aurner's interpretation. ${ }^{1}$ Educational reform, however, must be understood in the context of antebellum Iowa political culture and the ideology of common school reform. Legislation to create the Iowa system of public education accompanied Iowa's participation in the developing national market economy. Educational reform was also part of the institution building fostered by leaders of the recently created Republican Party and supported by the majority of that party and some members of the Democratic Party. Finally, the expansion across the country of public schools devoted to inculcating a middleclass culture of character and self-improvement was an integral

I am indebted to Jo Engelhardt for research assistance and to the Annals of Iowa's editor and three anonymous readers for thoughtful criticisms.

1. Clarence Ray Aurner, "Some Early Educational Leaders in Iowa," Iowa Journal of History 22 (1924), 532; idem, History of Education in Iowa, 5 vols. (Iowa City, 1914-1920), 1:30; Vernon Carstensen, "The University as Head of the Iowa Public School System," Iowa Journal of History 53 (1955), 213-46; Jacob A. Swisher, "A Century of School Legislation in Iowa," Iowa Journal of History and Politics 44 (1946), 174-204.

THE ANNALS OF IOWA 56 (Summer 1997). CThe State Historical Society of Iowa, 1997. 
part of the market revolution. ${ }^{2}$ These converging economic, political, and cultural forces provided the social context for the educational awakening promoted by Iowa's political and educational leaders.

HISTORIAN ROBERT COOK has synthesized recent studies of Iowa's party politics and economy to describe the antebellum political culture of the state. Iowa "boomed" during most of the 1850s. Population more than tripled to 674,913 , and population density increased from 4.1 to 12.2 persons per square mile between 1852 and 1860. By 1860, Iowa was one of the most productive farm states nationally, producing large surpluses of corn, wheat, and pork. The advent of railroads stimulated immigration and integrated Iowa into the national market. By the early 1850s, Dubuque, Davenport, Burlington, and Keokuk were competing to link themselves to the national rail network. Local competition for commercial supremacy cut across party lines. In Burlington, for example, leading Whig James W. Grimes cooperated with Democrats Charles Mason, William F. Coolbaugh, and Jonathan $C$. Hall to secure a Chicago railroad connection via Quincy, Illinois. Rapid population and economic growth transformed Iowa society, politics, and education and stimulated the development of infrastructure. Railroads, banks, and schools became issues of political debate between Democrats and Whigs. ${ }^{3}$

Democratic and Whig leaders were generally native born, urban, and more wealthy, better educated, and more cosmopolitan than their constituents. Whigs tended toward evangelical Protestantism and opposed the rising political influence of Irish Catholics. They were supported by "Yankee" Congregationalists, Presbyterians, Quakers, and others who led moral reform efforts.

2. See Charles Sellers, The Market Revolution: Jacksonian America, 1815-1846 (New York, 1991), 364-69; and Ronald E. Butchart, "Education and Culture in the Trans-Mississippi West: An Interpretation," Journal of American Culture 3 (1980), 354-60.

3. Robert Cook, "The Political Culture of Antebellum Iowa: An Overview," Annals of lowa 52 (1993), 228-31; idem, Baptism of Fire: The Republican Party in Iowa, 1838-1878 (Ames, 1994), 4, 9-11, 95-97. 
Democrats, who were more tolerant of the state's diverse European ethnic groups, attracted the support of upcountry southerners and Irish and German Catholics. They dominated the state's early political history by pursuing a policy of negative government and free market economics. They opposed banks and government intervention to enforce temperance, antislavery, and the Sabbath. Whigs campaigned for government enforcement of Protestant moral standards and government assistance to banks, railroads, and other internal improvements to foster economic growth. Both parties were racist, but Democrats were more Negrophobic and Whigs more paternalistic toward blacks. ${ }^{4}$

Democratic dominance in the state ended in 1854 when the antislavery Whig James W. Grimes won a narrow victory for the governorship by opposing the Kansas-Nebraska Act and praising positive government. In February 1856 Grimes helped found the Republican Party, a coalition of Democrats opposed to the expansion of slavery into United States territories and antislavery Whigs. The Whig emphasis on positive government to expand banks, railroads, schools, and other internal improvements added to Republican electoral strength. Republicans incorporated the short-lived Know Nothing movement, sharing its concerns about religion, patriotism, and morality as the foundation of American culture. Such values were fundamental to the creation of an Iowa system of public education. Democrats fought back by attacking Republicans as abolitionists, disunionists, and miscegenationists. But time and events were against them. Iowa commercial farmers feared the competition of slave labor and wanted the infrastructure provided by the Republican program of banks, transportation, and schools. ${ }^{5}$

Iowa's commercial development, population growth, and emerging Republican Party all contributed to the growing demand for educational reform of Iowa's public schools, which

4. Cook, "Political Culture of Antebellum Iowa," 231-41.

5. Ibid., 244-49. See also Ronald Matthias, "The Know Nothings in Iowa: Opportunity and Frustration in Antebellum Politics," Annals of lowa 53 (1994), 39-41; Eric Foner, Free Soil, Free Labor, Free Men: The Ideology of the Republican Party before the Civil War (New York, 1970), 302-4, 309-11, 316-17; William E. Gienapp, The Origins of the Republican Party, 1852-1856 (New York, 1987), 122, 278-79, 422-37. 
many considered inadequate and unsystematic. During early settlement, individual neighborhoods created schools according to familiar customs under school laws transferred from New England to Iowa by way of Michigan and Ohio. The first law, "An Act Providing for the Establishment of Public Schools," was passed by the first territorial legislature and approved on January 1,1839 . It authorized county authorities to establish districts and to levy taxes for support of schools "for every class of white citizens between the ages of five and twenty-one years." Under this permissive legislation, citizens had organized four hundred districts by the time Iowa became a state in 1846 . The new state constitution stipulated that the General Assembly should provide for the election of a state superintendent of public instruction, maintain a school fund, and provide for the maintenance of a common school in each school district for at least three months each year. This legislation authorized, but did not mandate, the establishment of public schools in each district. Robert Lucas, the first territorial governor (1838-1841), and subsequent governors and state superintendents found these legislative provisions inadequate. They repeatedly demanded that the General Assembly create a unified educational system. ${ }^{6}$

What did Iowa politicians and school reformers mean when they called Iowa schools and school law inadequate and demanded a unified educational system? According to the ideal of common school reformers, schools should be free: that is, they should be open to all children of the community. Iowa schools were not free. The principle of compulsory taxation to fund local public schools had not yet been accepted by 1850 in Iowa and most other midwestern states. Common schools were still funded by rate bills - tuition payments made by students once public funds had been expended. Reformers worried about the high number of children who either did not attend or else attended infrequently. In 1853, for example, Iowa had 100,083 persons between 5 and 21 years; of these school-age children

6. 1839 School Law, quoted in Arnie Cooper, "A Stony Road: Black Education in Iowa, 1838-1860," Annals of lowa 48 (1986), 114; Leonard Parker, "Teachers in Iowa Before 1858," Iowa Historical Lectures (lowa City, 1894), 45, 34, 28; Aurner, History of Education in Iowa, 1:235-39; Swisher, "Century of School Legislation," 174-76; Carstensen, "University as Head," 215-16. 
only 42.4 percent ever attended school and only 24.5 percent attended regularly. Common school reformers also complained in 1857 that nearly 20 percent of the state's 3,265 districts failed to maintain schools, a number they feared might grow due to ambiguities in Iowa school law and lack of local initiative. Thus the number of new schools would not keep pace with Iowa's rapidly expanding population. Finally, reformers worried that schools were employing unsuitable persons to teach and that there was no supervision to ensure the educational fidelity of teachers or students. To correct all of these problems-poor attendance, insufficient schools, inferior teachers, and no supervision - Iowa common school reformers urged the creation of a unified system of tax-supported free schools.?

IOWA SCHOOL REFORMERS - members of the Iowa State Teachers Association (ISTA), editors of early school journals, state superintendents, governors, and other political leadersused speeches, journal articles, resolutions, petitions, and reports to articulate the ideology of common school reform. A coherent, integrated set of republican, Protestant, and capitalist social beliefs, this ideology provided the rationale for organizing a state system of common schools. The common school ideology expressed values similar to the free labor ideology of the Republican Party. Both were rooted in the Protestant ethic and in capitalism. Both appealed to the middle class by maintaining that individual character determined success and contributed to social mobility and economic growth. Thus both were shaped by and contributed to the national market revolution. The ideologies differed in that the common school ideology - recognizing the anarchy implicit in economic individualism - appealed to the notions of civic virtue and political community emphasized

7. R. Freeman Butts and Lawrence A. Cremin, $A$ History of Education in American Culture (New York, 1953), 247-49, 252; Swisher, "Century of School Legislation," 177-78; Aurner, History of Education in Iowa, 1:235-39; Superintendent of Public Instruction, Report, in Legislative Documents of Iowa General Assembly, 1857, 12-13 (hereafter cited as Supt. P.I. Report and Leg Doc); Supt. P.I. Report, in 1855 Iowa Senate Journal, 137-39. 
by the tradition of classical republicanism. ${ }^{8}$ Thus the common school ideology attempted to tame the market revolution by erecting common schools as a bulwark of civic virtue.

John A. Parvin of Muscatine, a moderate Republican and first president of the ISTA, emphasized the common school ideology in his inaugural address delivered in 1854. A republican government, Parvin stated, required an educated people. "Equal laws, free institutions, and civil and religious liberty, cannot exist, while the people who make the laws, are ignorant, superstitious and vicious." In common schools, places of mental and moral culture, children from all classes would develop fraternal feeling by being educated together. They would be informed about public affairs so they could vote on important questions. They would learn about their individual rights so these could be maintained. And, Parvin argued, by imparting a homogeneous culture, common schools would be assimilationist: children of immigrants would "become Americans in feeling, in sentiment, and in language."

Democrat James D. Eads, state superintendent of public instruction (1854-1857), also articulated the ideology of common school reform in his annual reports. Asserting that "the intelligence of the masses is the main pillar of popular liberty," Eads lamented the deficiencies of the existing system and urged a thorough and prompt revision of the school laws. Because the school fund could not adequately support a system of free schools, he proposed a graduated tax on property. He also argued that

8. For an informative discussion of the ideology, see Carl F. Kaestle, Pillars of the Republic: Common Schools and American Society, 1780-1860 (New York, 1983), 75-103; and idem, "Ideology and American Educational Experience," History of Education Quarterly 22 (1982), 123-37. Foner, Free Soil, Free Labor, Free Men, 11-15 and 27-28, discusses free labor ideology. The relationship of Lockean individualism and classical republicanism is discussed in Rogers $M$. Smith, "'The American Creed' and American Identity: The Limits on Liberal Citizenship in the United States," Western Political Quarterly 41 (1988), 231-45; Richard C. Sinopoli, The Foundations of American Citizenship: Liberalism, the Constitution and Civic Virtue (New York, 1992), 7-10; Mark E. Kann, On the Man Question: Gender and Civic Virtue in America (Philadelphia, 1991), 9, 39, 226.

9. John A. Parvin, "The Necessity of Universal Education in the United States," in Iowa State Teachers Association, Proceedings of the Annual Convention, 1854, reprinted in ISTA, Proceedings, 1893, 115-16, 120. 
school law should provide for the organization of "union or Graded Schools" in cities and large towns because they would enable more efficient elementary instruction and more advanced studies to prepare scholars for the university. To benefit common schools by elevating "the business of teaching," he urged the General Assembly to establish a state normal school. Finally, he advocated the creation of a school journal to arouse and enlighten the public mind on the necessity for common school reform. ${ }^{10}$

Governor James W. Grimes (1854-1858), a New Hampshire native who had attended Dartmouth College before coming to Burlington in 1836, did more than anyone else to give political voice to the cause of common school reform. A Whig who helped form the state's Republican Party, Grimes shared the Whig view that the state should act to improve the economy, shape morals, and unify culture. Thus he believed that common schools should be centralist, assimilationist, and moralistic. ${ }^{11}$

He stated these beliefs clearly in his inaugural address. Beginning with the premise that "government is established for the protection of the governed," Grimes insisted that "it would fall far short of its design if it did not disseminate intelligence and build up the moral energies of the people." Noting that all "agreed that the safety and perpetuity of our republican institutions depends upon the diffusion of intelligence among the masses of the people," Grimes recommended the adoption of "a more efficient system of common schools than we now have." 12

Grimes stressed the moralist and capitalist aspects of the common school ideology as well as its republican strand. As a spokesman for the aspirations of Iowa's urban and rural middle class, Grimes saw education as a way to prepare individuals to participate in the market revolution; at the same time, civic virtues learned in school would protect the community. As

10. Supt. P.I. Report, in Leg Doc, 1856, 655-56, 658-59, 663-64; Supt. P.I. Report, in Appendix to the 1854 lowa Senate Journal, 158-60.

11. Irving H. Hart, "The Governors of Iowa as Educational Leaders, 18381949," Iowa Journal of History 54 (1956), 236; Benjamin F. Shambaugh, ed., The Messages and Proclamations of the Governors of Iowa, 7 vols. (Iowa City, 1903), 2:3-4; Kaestle, Pillars of the Republic, 76-77.

12. "Inaugural Address of Governor Grimes," Appendix to the 1854 Iowa Senate Journal, 14-15. 
"the best preventive of pauperism and crime" and as "the great equalizer of human conditions," education clearly prepared rich and poor for careers "of usefulness and honor" and thereby enhanced the security of property. Because private property benefited from "the conservative influences of education," Grimes believed it "should be made to pay for its own protection." Thus reform, he argued, would require adopting property taxes in place of the existing rate system. ${ }^{13}$

The ideology of common school reform also carried assumptions about ethnicity, race, and gender. Although the portion of foreign-born in Iowa's population was only about one in seven in 1856, nativist fears about increasing foreign immigration may have contributed to the short-lived Know Nothing movement that appeared between 1854 and 1856. Both Parvin and Grimes echoed that movement's patriotic concerns by arguing that common schools should assimilate immigrant children into American culture. Race was a much more divisive issue. Only a minority of Republicans insisted that blacks and whites should attend integrated schools. Democrats strongly maintained that schools should be segregated. The 1857 state constitution's affirmation of districts' popular sovereignty represented a compromise on this issue. ${ }^{14}$

Coeducation and equal education for women were not contested issues. In keeping with the gender assumptions implicit in the common school ideology, Iowa educators maintained that women must be educated. By the 1820 s, educational reform journals - Common School Journal, American Journal of Education, and The Annals of Education - carried numerous articles arguing that women should be educated to enable them to better fulfill their maternal and domestic roles. As Benjamin Rush had stated three decades earlier, well-instructed mothers were responsible for inculcating in their sons the republican virtue and morality necessary for maintaining a stable republic. Catharine Beecher extended the argument for republican motherhood to include training female school teachers for the "uncivilized" West. These ideas were echoed in Iowa. In 1855 the Fairfield Ledger lamented

13. Ibid.

14. Matthias, "Know Nothings," 32-38. 
the preponderance of male over female teachers in the state because "Females are the best teachers of rudimentary schools, ... which they alone can conduct successfully." Two years later the Cedar County Teachers' Institute resolved "that woman is equally capacitated with man to discharge duties of teacher." By 1860 , the number of female teachers $(1,682)$ exceeded the number of male teachers $(1,118)$. The Civil War accelerated this trend toward the feminization of teaching. Several of the emerging majority of women teachers were active in the incipient profession, making presentations at meetings of the ISTA and publishing in early education journals. ${ }^{15}$

An unsigned article in Voice of Iowa (1857) and one by S. H. Weller in Iowa Instructor (1859) provided intellectual justifications for women's education and coeducation. The former maintained that every mother is an educator as a model of virtues to her children; hence women ought to be trained to reason rightly as well as learn the skills of keeping house and household accounts. Weller argued that despite "an acknowledged inferiority in the intrinsic power of the female mind," women should be allowed to compete with young men for the highest honors in college study, so that "the present superficiality in female education will be superseded by minds adorned with intellectual excellence." Weller insisted that coeducation in colleges would work as well as it did in common schools if parental discipline were applied to school government. Women would especially benefit because being educated with men would curb their natural tendencies toward "dissipation of mind" and "excessive emotion. ${ }^{.16}$ Others

15. Mary Hurlbut Cordier, "Prairie Schoolwomen, Mid-1850s to 1920s, in Iowa, Kansas, and Nebraska," Great Plains Quarterly 8 (1988), 118 and 104; Nancy F. Cott, The Bonds of Womanhood: "Woman's Sphere" in New England, 1780-1835 (New Haven, CT, 1977), 118-22; Fairfield Ledger, 22 March 1855; "Notes from the Field: Cedar County Teachers' Institute," Voice of Iowa: Monthly Journal of Civilization 1 (February 1857), 50-53; Evelyn Clinton, "Dare We Do Right," Voice of Iowa 1 (June 1857), 174-75; idem, "Habits of Intellect," ibid. 2 (August 1857), 61; Emma J. Goss, "Teachers Duties," ibid. (December 1857), 181-83; Thomas Morain, "The Departure of Males from the Teaching Profession in NineteenthCentury Iowa," Civil War History 26 (1980), 161-70.

16. "Education of Women and Women as Educators," Voice of Iowa 1 (November 1857), 154-60; S. H. Weller, "Coeducation of the Sexes," Iowa Instructor 1 (November 1859), 33-38. 
in Iowa must have agreed. The recently founded State University of Iowa was the first coeducational public university in the United States.

WHIG-REPUBLICAN INSTITUTION BUILDING in a marketdriven and expanding frontier state was evident at the special session of the Fifth General Assembly called in July 1856 to consider railroad land grants. Addressing the session, Governor Grimes again raised the issue of common school reform. He regretted that the resolution passed by the House in each of the previous two legislative sessions authorizing a commission for school law revision had not passed the Democrat-controlled Senate, and he insisted the state could not risk further delay. Implying that it was impossible for the General Assembly to consider the complex issue in only fifty days and charging that "our school system is without unity and efficiency, and is, in my conviction, discreditable to the state," Grimes recommended that a commission of three persons be appointed to propose revised school laws to the next General Assembly. In lieu of that, the General Assembly should at least divest the superintendent of public instruction of the control and responsibility for school lands and funds. The superintendent's office had not been designed for the custody of public monies, the governor maintained; its legitimate duties were the supervision of schools. ${ }^{17}$

In the Fifth General Assembly there were 17 Democrats and 14 Whigs in the Senate and 40 Whigs and 31 Democrats in the House. On July 9 the Whig-dominated House passed HF 21 authorizing a school commission without a roll call. Less than a week later, the Democrat-controlled Senate passed HF 21 by a relatively narrow margin of 16 yeas (11 Whigs and 5 Democrats) to 11 nays ( 3 Whigs and 8 Democrats). Two of the five Democrats who voted for passage later joined the Republican Party; moreover, eight negative votes came from areas of south-

17. James W. Grimes, "Message to the Special Session," Messages and Proclamations, 2:19-20; Iowa City Daily Republican, 3 July 1856; 1856 Iowa Senate Journal (special session), 11. 
ern settlement and Democratic strength. ${ }^{18}$ As in most subsequent votes on common school reform, a majority of Republicans, joined by a minority of Democrats, voted in favor; a majority of Democrats, backed by a few Republicans, opposed.

Empowered by the General Assembly, Grimes appointed the three-man commission: Horace Mann, a nationally prominent common school reformer and president of Antioch College in Ohio; Amos Dean, University of Iowa president residing in Albany, New York; and Republican Judge Frederick E. Bissell of Dubuque. Bissell refused to serve, so Mann and Dean wrote the final report even though as nonresidents they lacked firsthand knowledge of the state. Commending the report to the General Assembly in December 1856, Grimes said it contained "the wisdom and experience of the best educationists of this country." The Mann Report, so-called because the distinguished founder of common schools in Massachusetts is better remembered than his coauthor, has been credited with beginning an educational renaissance in Iowa. ${ }^{19}$ It should also be understood as the culmination of efforts by lowa school reformers. Parvin, Eads, Grimes, and others had already argued the case for common schools in a Protestant, capitalist republic, and they had already agitated for many of the specific recommendations made by Mann and Dean.

The Mann Report, not surprisingly, expressed the ideology of common school reform. According to the report, Iowa required an adequate system of public education to attain "the full development of its great physical resources, and of the intellect and imoral power of its people." All Iowa youth, Mann and Dean asserted, were entitled to an education, and the state would ultimately benefit from their training. Because they shared the widespread nineteenth-century Romantic belief that property and material wealth "owes its existence to the mind," Mann and Dean maintained that it was fair to tax property to fund educa-

18. Iowa State Almanac and Statistical Register for 1860 (1860; reprint, Iowa City, 1963), 22; 1856 Iowa House Journal (special session), 37; 1856 Iowa Senate Journal (special session), 78; Cook, Baptism of Fire, 69.

19. Grimes, "First Biennial Message," Messages and Proclamations, 2:36; "Message from Governor Grimes," 1856 Iowa Senate Journal, 87-88; Aurner, History of Education in Iowa, 1:30-31, 36. 
tion. Finding that previous legislation was "entirely wanting in unity and completeness," the commissioners recommended a unified, tax-supported system of public education extending from elementary grades through the university. ${ }^{20}$ Their recommendations attempted to foster institution building by addressing the shortcomings identified in earlier agitation by Iowa common school reformers.

To finance common schools, the commission proposed a property tax levied by the county. Districts were responsible for building school houses, equipping them, and establishing district libraries. Once these responsibilities were met, districts received their share of county revenues. To increase efficiency, the commissioners suggested creating a three-tiered bureaucratic pyramid following the Massachusetts pattern of township and district supervision that had been copied by other New England and western states. The commission considered township districts more efficient than an excessive number of small districts. The county superintendent exercised financial and visitorial power over the district schools. Mann and Dean emphasized the potential benefit of the visitorial power "to make the District School known, to proclaim its merits, and to expose its defects." To further improve school supervision, county superintendents were to meet annually with district school board presidents in their respective counties and with the state superintendent of public instruction. These meetings, with their "careful collection of facts and free interchange of thoughts," Mann and Dean believed, would promote the educational interests of the state. ${ }^{21}$

Mann and Dean also provided "for institutions of learning higher than the primary school" because they knew that common schools could not flourish in an educational vacuum. High schools, for example, were to be established when a county's population reached twenty thousand. The commissioners suggested that high schools would receive greater community sup-

20. Report of the Commissioners of Revision of the School Laws, Appendix to the 1856 Iowa House Journal, 191-93; Aurner, History of Education in Iowa, 1:3236. See also John A. Beineke, "The Mark of Horace Mann on Iowa Education," Palimpsest 66 (1985), 101-5.

21. Report of the Commissioners, Appendix to the 1856 Iowa House Journal, 193-96, 198-99; Butts and Cremin, History of Education, 254-55. 
port if they were made part of the common school system. Moreover, such schools would make the state university more accessible to students of talent; at the same time, they could benefit the common schools by training teachers. The commissioners also proposed scholarships to the university for talented students who would be obligated to teach. These scholarships, Mann and Dean believed, would "excite everywhere among the young a noble ambition to be serviceable to the State and their fellow men." Mann and Dean recommended that the university normal department be supported by the common school fund because it "stood at the head" of the common school system. A provision for teachers' institutes rounded out their proposed educational system for Iowa. ${ }^{22}$

The Mann Report recognized that structural reorganization was necessary but not sufficient for improving the common schools. Talented teachers were required as well: "No common school system can ever succeed where the compensation is so meager as to encourage only those of the most ordinary talents and attainments to embark on it." The commissioners admitted that teachers should be motivated by more than pecuniary reward, but insisted that compensation indicated "the high or low estimate which a community places upon the character of the service." To have good schools, therefore, communities would have to tax themselves sufficiently to attract superior teachers. ${ }^{23}$

Despite the educational prestige of Horace Mann and Amos Dean and the emphasis Governor Grimes placed on common school reform, Iowa newspapers gave little coverage to the Mann Commission and its report. Because virtually all newspapers of this period in Iowa and throughout the United States openly avowed the cause of one or the other major party, partisan emphasis on the slave power, black Republicans, and bleeding Kansas tended to displace discussion of educational issues, with Democratic newspapers giving much less attention to education than Whig-Republican newspapers. In general, though, the newspapers reveal a pattern similar to the party votes on common school

22. Report of the Commissioners, Appendix to the 1856 lowa House Journal, 193-94, 196, 199.

23. Ibid., 197. 
reform. The Iowa Democratic Enquirer, after grousing that Iowa commissioners could have been found to revise the school laws, summarized the Mann Commission Report without comment. Republican newspapers were more supportive. The Burlington Hawkeye and Telegraph praised the report "for its wise suggestions," and the Tipton Advertiser said that the proposals seemed well suited to educate all citizens of the state. ${ }^{24}$

Republicans dominated the Sixth General Assembly, which met in December 1856, outnumbering Democrats 24 to 12 in the Senate and 44 to 28 in the House. With the Republican majority divided on the race issue and the Democratic minority opposed to admitting African-American children to public schools, race played a key role in legislators' failure to pass the school legislation based on the Mann Commission Report. In the Senate, Republican William Hamilton of Dubuque County amended the bill to read "colored children should not be admitted without unanimous consent of householders [in a district] nor shall property of colored persons be taxed for school purposes." The first clause of the amendment was adopted by a vote of 24 yeas (15 Republicans, 8 Democrats, and 1 unidentified) to 8 nays ( 7 Republicans and 1 Democrat); the second clause was adopted by a vote of 27 yeas (22 Republicans and 5 Democrats) to 5 nays ( 3 Democrats and 2 Republicans). Democrat William Coolbaugh's attempt to strike "without unanimous consent of householders" failed on a vote of 12 yeas (4 Republicans and 8 Democrats) to 20 nays ( 18 Republicans, 1 Democrat, and 1 unidentified). The attempt to order the bill, which included the provision that district secretaries would not enumerate African-American chil-

24. William E. Gienapp, "Politics Seem to Enter into Everything': Political Culture in the North, 1840-1860," in Essays on American Antebellum Politics, 18401860 , ed. Stephen E. Maizlish and John J. Kushma (College Station, TX, 1982), 41-42; Iowa Democratic Enquirer (Muscatine), 29 December 1856; Burlington Weekly Hawkeye and Telegraph, 31 December 1856 and 7 January 1857; and Tipton Advertiser, 20 December 1856. I examined five Democratic and seven Whig-Republican newspapers: in addition to the Muscatine paper cited, the Democratic papers were Daily Iowa State Democrat (Davenport), Fayette County Pioneer (West Union) Iowa State Journal (Des Moines), and Ford Dodge Sentinel; besides the Tipton and Burlington papers, the Republican papers were Iowa City Weekly Republican, Des Moines Valley Whig, Keokuk Gate City, Vinton Herald, and Fairfield Ledger. 
dren, for a third reading was refused by a vote of 14 Republican yeas to 15 nays (8 Republicans and 7 Democrats). Race probably accounts for the negative votes. Democrats feared that African Americans might be admitted to public schools, and Republicans resented that black rights were not sufficiently protected. Meanwhile, the education bill in the House was indefinitely postponed by a vote of 35 to 18 due to lack of time for consideration. Vote by party reveals strong Democratic support for postponement (16 to 2), while Republicans divided almost evenly on the issue (19 yeas to 16 nays). Democrats may have voted to postpone because they were indifferent or hostile to particular aspects of common school reform. The race issue may have led several Republicans to vote for delay, while commitment to common school reform may account for Republican opposition to postponement. ${ }^{25}$

Educational reformers were disappointed by the lack of legislative action. Besides the divisive race issue, lack of time appears to have been a factor. Perhaps, as the Iowa Democratic Enquirer reported in December, the General Assembly had been very. busy debating the situation in Kansas. The legislature certainly was busy angrily debating and investigating the corruption of Democratic Superintendent of Public Instruction James D. Eads. Republicans charged that Eads had defaulted on $\$ 100,000$ of the school fund which he had used for land speculation or had illegally loaned to Democratic newspapers. Not to be outdone in partisan attacks, Democrats charged Governor Grimes with attempting to wrest the school fund from the superintendent of public instruction for the purpose of "Black Republican electioneering. ${ }^{26}$ The Eads investigation dragged on for several

25. Iowa State Almanac and Statistical Register, 1860, 23; 1856 Iowa Senate Journal, 432, 444-47; 1856 Iowa House Journal, 489-90; Aurner, History of Education in Iowa, 2:122. During debate, George W. Ells, a Radical Republican delegate from Scott County, attributed the bill's defeat to the race issue. The Debates of the Constitutional Convention of the State of Iowa, 1857, 2:728-29.

26. Burlington Daily Hawkeye and Telegraph, 13 and 17 January and 3, 5, and 12 February 1857; lowa Democratic Enquirer (Muscatine), 31 July and 29 December 1856; Daily Iowa State Democrat (Davenport), 18 July and 9 December 1856; Fairfield Ledger, 31 July 1856 and 15 January 1857; Tipton Advertiser, 26 July and 13 December 1856. 
years. Its immediate effect was to distract legislative attention from the school bill and to focus attention on changing the office of the superintendent of public instruction.

Despite its failure to achieve comprehensive educational reform, the Sixth General Assembly did pass without roll calls the "union school" bill authored by Christopher C. Nestlerode, a Tipton teacher, who was aided by Cedar County Republicans Jonathan W. Cattell in the Senate and Ed Wright in the House. The law provided that towns with a population of two hundred or more might be organized in a single school district if electors approved. These schools would be financed by a property tax levy supplemented by pro rata assessment on those attending. ${ }^{27}$

UNDAUNTED by their legislative defeat, educational reformers shifted their hopes to the constitutional convention that met in early 1857. Reform hopes were stated in the first issue of a new publication-The Voice of Iowa: Monthly Journal of Civilization. During its brief existence (1857-1858), the Voice contributed vigorously to the campaign for common school reform. Edited by James L. Enos, a newspaper man who was elected president of the ISTA in 1856 and who would remain active as a speaker at teachers' institutes until 1868, the Voice advocated free schools, considered itself the organ of the state superintendent, and provided the means of communication between the ISTA and the Iowa Phonetic Association, which also pledged its support to free education. In its premiere issue, the Voice noted the prominent defects of the Iowa school system. First, Iowa schools were not free because special taxes were levied on scholars in all districts. Second, the state did not provide for the professional education of teachers. Third, Iowa lacked efficient supervision of the schools. The Voice called on the impending constitutional convention to remedy these defects. ${ }^{28}$

27. Aurner, History of Education in Iowa, 1:36-38; 1856 Iowa House Journal, 480; 1856 Iowa Senate Journal, 430.

28. Aurner, "Early Educational Leaders," 560-63; "The Iowa School System," Voice of lowa 1 (January 1857), 16-17. 
The constitutional convention, consisting of 21 Republican and 15 Democratic delegates, had been called at the instigation of the new Republican Party to create a banking system. Once again the connection of Republican institution building to the market revolution and education are evident. Not only did the Republican majority at the convention respond to the market revolution by institutionalizing banks, they also gave careful attention to common school reform. The five-member committee on education was the largest of the convention. Debates on education reflected concerns about the recent failure of the General Assembly to enact the Mann Commission recommendations and the financial troubles of the superintendent of public instruction. The debates also reveal a somewhat surprising consensus - in light of party divisions in the General Assembly - on the issue of public education. Delegates from both political parties agreed that the state had an obligation to establish free schools. The ideology of common school reform provided the rationale: "Knowledge and learning . . . being essential to the preservation of a free government, it shall be the duty of the General Assembly ... to provide by law for a system of common schools, wherein tuition shall be without charge, and equally open to all." ${ }^{29} \mathrm{De}-$ spite agreement on the need for free schools, delegates disagreed sharply about the issues of creating a board of education and admitting African Americans to public schools. Delegates did not address the bureaucratic and centralizing recommendations of the Mann Commission, which might have revealed Republican and Democratic party differences on those aspects of common school reform.

As a result of the rejection of common school reform by the General Assembly and the controversy surrounding Superintendent Eads, the convention followed a Mann Commission recommendation to create a board of education empowered to make rules and regulations for common schools and other institutions of learning. Voters would elect eleven members to four-year terms, and the board would appoint a secretary as its executive

29. Aurner, History of Education in Iowa, 2:114-15; Leland L. Sage, A History of Iowa, (Ames, 1974), 134-38; Debates of the Constitutional Convention, 1857, 1:ii, 78-79. 
officer. Although the board would have the full power to legislate for the schools, it could not levy taxes or appropriate money, and the General Assembly could amend or repeal its regulations. Delegates accepted the board as an experiment that might improve the common schools after the recent failures by the General Assembly and the state superintendent of public instruction, but they would not have accepted it without the provision that it might be abolished after five years. ${ }^{30}$

Delegates Jonathan C. Hall and James F. Wilson sharply debated the role of the board of education. At issue was whether or not the General Assembly, now controlled by the Republican Party, should directly legislate common school reform. Wilson, an Ohio-born Republican lawyer, charged that electing board members created a fourth branch of government, one not subject to the governor's veto and one whose legislative powers would bring frequent clashes with the General Assembly. The board's broad powers, Wilson charged, were tyrannical and potentially dangerous to the liberties of a free people. ${ }^{31}$

Hall, a Democratic former member of the lowa Supreme Court, defended election of board members against Wilson's suggestion that they be appointed by the General Assembly. For the board "to give efficiency to the cause of education," Hall argued, "you must make them something more than mere ministerial officers, something more than mere drudges to carry out the will of the legislature." An elected board would operate more efficiently, Hall maintained, because its members would be well qualified and devoted to the cause of education. Moreover, it would be separated "from the wild and hurried scramble of the political arena," which was an advantage, according to Hall, because "the General Assembly is not a fit body to manage and have jurisdiction of the system of education." Hall also denied that political tyranny could result from creating and electing a board of education. By furthering the cause of common school reform, the board would enhance the people's reason, intelligence, and morality. Therefore, electing the board could

30. Debates of the Constitutional Convention, 1857, 2:1087-88; Aurner, History of Education in Iowa, 2:106-13.

31. Debates of the Constitutional Convention, 1857, 2:748-50 and 1:600-602. 
"never endanger our liberties" and never "nurse the viper of tyranny or despotism." Hall's belief that republican liberty depended on public education was so compelling that he even took a position unthinkable for most Democrats: he endorsed the principle of compulsory education even though he recognized that it would be perceived as an infringement on individual liberty. ${ }^{32}$

The issue of integrated schools also provoked bitter debate among convention delegates. The racism Iowans shared with residents of other western states was evident in the several restrictions on immigration, suffrage, and education that Iowa had enacted earlier against blacks. Although the 1856 census listed only 271 African Americans in the state, many Iowans feared integration. In an 1856 letter, Democratic State Superintendent James D. Eads asserted that "colored persons have no claims whatever to any part of the School Fund" because they "are not and cannot become citizens of the state under the existing laws." Democratic delegate Jonathan Hall took a more enlightened, yet segregationist, view of this issue at the convention. He argued that the state should educate blacks and Indians, but opposed inserting "in our Constitution anything by which that class of people could force themselves into schools designed exclusively for the education of white people." Racial fears led the convention to reject the wording that schools be "equally open to all" as proposed by A. H. Marvin, a Republican farmer from Jones County. Finally, the delegates, at the request of Scott County Republican George Ells, inserted into the constitution the clause, "for the education of all the youth of the state through a system of common schools." ${ }^{\prime 33}$

According to Robert R. Dykstra, Republican constitutional delegates responded to resolutions from the state's first colored convention, which met January 5, 1857, in Muscatine. That con-

32. Ibid., 2:725-27, 753, 820-21; Edward H. Stiles, Recollections and Sketches of Notable Lawyers and Public Men of Early lowa (Des Moines, 1916), 20-23, 31.

33. Foner, Free Soil, Free Labor, Free Men, 261-67; James D. Eads to Adams Hemperly, 10 January 1856, Correspondence of the State Superintendent of Public Instruction, State Archives of Iowa, State Historical Society of Iowa, Des Moines; Debates of the Constitutional Convention, 1857, 2:728-29, 835; Sage, History of Iowa, 136-37; Cooper, "Stony Road," 126-29. 
vention petitioned for all of the rights of citizenship, including the right to vote and the right to public education. Consequently, Muscatine's Republican delegate John A. Parvin moved that the committee on schools provide for the education of colored children. Although Republican delegates were more egalitarian than their Democratic counterparts, they disagreed about racially integrated schools. Conceding the existence of racist opinion in Iowa, delegates left school integration strictly to local school boards. Nonetheless, influenced by Parvin, all Republican delegates voted against constitutionally imposing school segregation. ${ }^{34}$

The constitutional provision for public education was finally adopted with the bipartisan support of 11 Republicans and 12 Democrats. The race issue accounts for the negative votes of 7 Republicans, for whom the convention's compromise on the issue of integrated schools was not acceptable. In addition, James F. Wilson voted no perhaps because of his strong opposition to the board of education. ${ }^{35}$

Race also played a role in the struggle to secure enough popular support to ratify the new constitution. Republican leaders worked to balance radical demands for black rights (including suffrage) with the need to win elections. Warned by James F. Wilson and John Edwards that a constitution including black rights might not be adopted, Republicans compromised by separating the referendum on black suffrage from the one on the constitution. Still, frustrated Democrats used racism to place Republicans on the defensive, attacking the "Republican" constitution for its provisions on black suffrage as well as those on banks, corporations, and state debts. Republicans responded by distancing themselves from suffrage reform, which was not part

34. Robert R. Dykstra, Bright Radical Star: Black Freedom and White Supremacy on the Hawkeye Frontier (Cambridge, MA, 1993), 151, 154-57, 167-68.

35. Debates of the Constitutional Convention, 1857, 2:1030. According to Dykstra's racial egalitarian scale, the two Republican progressives (Bunker and R. L. B. Clarke), three moderates (W. P. Clarke, Gray, and Traer), and three conservatives (Wilson, Winchester, and Young) had all (with one exception) supported equal rights for blacks on three previous roll calls dealing with education. The exception, S. G. Winchester, had voted in favor of Hall's motion to table Marvin's substitute specifying that the common schools "shall be free of charge and open to all." Dykstra, Bright Radical Star, 158-59. 
of the constitution. The Republican Fairfield Ledger charged that Democratic attacks on the "expensive" board of education and admitting black youth to public schools were poisoning minds by misrepresentation. Expenses for the board of education would be partially funded by savings from eliminating the state superintendent of public instruction and the school fund commissioners. Moreover, Democratic delegates at the constitutional convention, led by Jonathan $C$. Hall, had voted for creation of the board, which was left free to establish separate schools for blacks. Despite bitter partisan attacks by Democrats, the new constitution was narrowly approved $(40,311$ to 38,681$)$, while black suffrage was crushingly defeated $(49,387$ to 8,489$)$. The constitution became Iowa's supreme law on September $3,1857 .^{36}$

ADDRESSING THE 1858 GENERAL ASSEMBLY, Governor Grimes continued the Republican Party's institution building efforts. He stated that the constitutional recommendations for education, if carried out, would greatly benefit the state. The board of education, according to Grimes, "will stimulate the zeal of the people ... in behalf of education" and "secure the uniform execution of the school laws throughout the commonwealth." Grimes argued that the new constitution removed the obstacles to passing the recommendations from the Mann Commission Report, and he again urged their adoption. "The public schools should be supported by taxation of property," he claimed, because they are "a public benefit for which the public should pay." ${ }^{\text {"37 }}$

Grimes's ideas were echoed in Christopher C. Nestlerode's presidential address to the ISTA and in Superintendent of Public Instruction Maturin L. Fisher's report to the legislature. Nestlerode had come to Tipton, Iowa, from Ohio in 1856 to establish the state's first union school (a school combining two or more districts and the common school with the academy). The school was founded under legislation passed by Nestlerode's Republican associates in the Sixth General Assembly. In addition, he

36. Cook, Baptism of Fire, 80-86; Dykstra, Bright Radical Star, 172-73; Fairfield Ledger, 21 May 1857; Sage, History of Iowa, 136-38.

37. Grimes, "Second Biennial Message," Messages and Proclamations, 2:45-46, 48. 
conducted teachers' institutes (1856-1875), twice served as president of the ISTA (1857 and 1862), and edited the ISTA school journal, Iowa Instructor (1859-1861). Nestlerode coined the term "school killers" to describe opponents of property taxes to support common schools. In his address, Nestlerode emphasized the republican, Protestant, and capitalist beliefs of the common school ideology. A property tax was justified, he maintained, because "good schools enhance and render secure all the property in their vicinity" and "poor schools tend to depreciate and render insecure all property in their vicinity." Nestlerode also believed that the moral training provided by free schools "is the cheapest and best way to suppress vice and prevent crime" and to make "every child . . . a useful citizen, a well prepared business man or woman." Fisher, a Democrat and a former threeterm state senator, insisted in his report that revision of the school laws could no longer be postponed. His recommendations paralleled those of the Mann Report: distribute tax revenues equally among districts of the county, elect county superintendents to supervise district schools and certify teachers, and create high schools to train common school teachers. Fisher drafted a bill incorporating these recommendations and worked closely with Republican Senators Jonathan W. Cattell and Josiah B. Grinnell to secure its passage. ${ }^{38}$

Despite a racist campaign waged by Democrats, the Republicans won a narrow victory in the 1857 fall elections and retained control of the governorship and the Seventh General Assembly by margins of 22 to 14 in the Senate and 42 to 30 in the House. The education reform bill, amended to permit racial integration of a school only with the "unanimous consent of the householders of the district," was challenged in both houses, prompting "warm," "spirited," and "lengthy" debate. In the Senate seven Republicans sought to alter "unanimous consent" to "consent of a majority" but were defeated overwhelmingly. In the House a similar effort won the vote of only twelve Republicans, although the majority refused, as they had in 1857, to mandate segregation.

38. C. C. Nestlerode, "Free Schools," Voice of Iowa 2 (December 1857), 166-67, 169; Supt. P.I. Report, in Leg Doc, 1857, 16, 23, 25; Aurner, "Early Educational Leaders," 551-53, 543-44; idem, History of Education in Iowa, 1:38-39. 
The "unanimous consent" version passed the Senate by a vote of 19 to 13 , with 16 Republicans and 3 Democrats voting in favor, 9 Democrats and 4 Republicans voting against, and 1 Republican and 1 Democrat not voting. The House passed the education reform bill by a vote of 45 yeas (34 Republicans and 11 Democrats) to 18 nays (10 Democrats, 7 Republicans, and 1 unidentified). This party vote revealed that Republicans continued to support common school reform by a large majority in both the House and Senate, while there was erosion of Democratic opposition in the House. Newspaper commentary also reflected this shift. Both Republican and Democratic newspapers emphasized a prevailing bipartisan spirit of cooperation and bipartisan support for the school law. Even Des Moines's Democratic Iowa State Journal pronounced the school law "good" and "worthy of a fair trial.".39

The 1858 School Law, the most extensive ever enacted in Iowa, incorporated the major recommendations of the Mann Commission Report. Its detailed provisions for establishing schools and its specific instructions for school officials were designed to promote systematic institution building in a newly settled and developing state. The act established civil townships as school districts, reduced presently organized districts to subdistricts controlled by township district boards, and permitted independent districts in towns with populations of one thousand or more. It empowered township voters to establish free elementary schools and to determine whether to found high schools in counties of sufficient population. The law provided for levying a county school tax and distributing the proceeds to schools. It gave detailed instructions for organizing districts and specified the duties of board members, secretaries, and township treasurers. It provided for higher education in county high schools and a state university, teacher training in teachers' institutes, scholarships to high schools and the university, and supervision of common schools by county and state superintendents. County superintendents were to examine and certify

39. Cook, Baptism of Fire, 94-95; Dykstra, Bright Radical Star, 192; Iowa State Almanac and Statistical Register, 1860, 23-24; 1858 Iowa Senate Journal, 296, 353; 1858 Iowa House Journal, 561-62; Burlington Daily Hawkeye, 24 February, 2, 5, and 13 March, and 1 April 1858; Clinton Herald, 20 and 27 February and 20 March 1858; Iowa State Journal (Des Moines), 13 February and 27 March 1858. 
teachers, visit schools, meet annually with school district presidents and the state superintendent of public instruction, and file annual reports of vital school statistics with the state superintendent's office. The state superintendent's duties were to keep records, distribute school laws, report to the board of education, and schedule and fund teachers' institutes throughout the state. Both county and state superintendents were charged with promoting the cause of public education through meetings, newspapers, circulars, and correspondence. ${ }^{40}$

Implementation of the new law soon after its publication in both Democratic and Republican newspapers in March 1858 sowed confusion and controversy. The first county superintendents were elected in April. Election of district school officers and organization of school districts soon followed. Several Republican newspapers praised the law as an improvement, urged that it be given a fair trial before it was changed, and worried about reports of opposition to the law's implementation. Opposition may have been based on the law's newness and complexity. The Democratic Fayette County Pioneer, published in West Union, complained that the law had "too much machinery attached," making it difficult for common people to understand. ${ }^{41}$

The anxieties of Iowa's common school reformers increased when the Iowa Supreme Court declared the new school law unconstitutional in December 1858. The court reasoned that under the new constitution the General Assembly could not pass laws providing for public instruction until a board of education was elected and organized. Fortunately for the cause of common school reform, more serious confusion was avoided when the newly elected board soon met and reenacted the school law. Pronounced constitutional by the Supreme Court, this action legalized what already had been done by the legislature. ${ }^{42}$

40. 1858 Laws of Iowa, 57-88; Aurner, History of Education in Iowa, 1:36, 49-57; Swisher, "Century of School Legislation," 179.

41. Tipton Advertiser, 27 March, 8 April, and 3 July 1858; Fairfield Ledger, 15 April 1858; Keokuk Gate City, 17 March 1858; Fayette County Pioneer (West Union), 5 and 12 April 1858.

42. Fairfield Ledger, 23 December 1858; District Township of Dubuque $v$ City of Dubuque (9 December 1858), Reports of Cases of Law and Equity, 7:262; Secretary, State Board of Education, Report, in Leg Doc, 1859, 3-4; ibid., 1864, 27. 
The board of education elected Thomas Hart Benton Jr., a Democrat, as secretary. A former state senator (1846-1848) and state superintendent of public instruction (1848-1854), Benton, as secretary of the board of education (1859-1863), assumed the duties of the state superintendent of public instruction, succeeding incumbent Maturin Fisher, and implemented the new law. He defended the law from attack, especially the provision for county superintendents, but rarely exercised his "semi-legislative" power. Iowa's professional educators united behind the legislation. The ISTA, meeting in August 1859, passed resolutions "in favor of the township district system and the office of county superintendent" and "heartily approve[d]" the school law without "serious alteration." The Voice of Iowa, soon to expire, said that the law "will give us an excellent educational system." The Iowa Instructor, replacing the Voice as the official organ of the ISTA and the new board of education, pledged itself as the law's "fearless advocate." In defending the law, the journal's editor pointed to the increased number of schools, teachers, and students attending since it had been enacted. ${ }^{43}$

ATTEMPTS TO REFORM common school reform began immediately. In the 1859 state elections, Democrats-detecting a Republican weakness on state issues - attacked their stands on prohibition, black suffrage, banking, state aid for railroads, and integrated public schools. The Democratic platform demanded. another complete overhaul of the school system. Conditions seemed to favor Democratic success. The state debt had climbed to over three hundred thousand dollars, taxes were relatively high, and the Iowa economy had not yet recovered from the Panic of 1857 and a series of crop failures from 1857 to 1859. Despite their seeming vulnerability, Republican Samuel Kirkwood narrowly won the governorship, and Republicans retained

43. Aurner, "Early Educational Leaders," 540-42; "Introduction to Vol. III," Voice of Iowa 3 (September 1858), 3; "Introductory," The Iowa Instructor 1 (October 1859), 3, 14, and 28-29; "The School Law in Poweshiek County," ibid. (November 1859), 57-58. 
control of the General Assembly by margins of 23 to 20 in the Senate and 49 to 37 in the House. ${ }^{44}$

In December 1859, following the election, the board of education met for a second time. Political issues spilled over into the meeting and dictated changes in the 1858 School Law. Petitioners demanded that the newly created office of county superintendent be abolished and independent districts be reestablished. In his report to the board and the General Assembly, Secretary Benton acknowledged several popular objections: too much expense, too intricate district organization, and the superfluous county superintendent. As a good Democrat, Benton wanted to be sensitive to the people's wishes, but he was reluctant to recommend wholesale change in the law, preferring instead "to make as few changes as possible in order to render it acceptable and useful to the people." He recommended continuing the township district because it gave "much more efficient and less expensive organization." Caught between popular demand and the secretary's recommendations, the board compromised. It retained the office of county superintendent but removed its school visitorial power. It maintained the township district but gave more voice to subdistricts and reduced the number of school officials by providing that subdirectors should compose the district board and choose a president and treasurer from their own number. The township clerk became ex-officio secretary and, in the absence of the president, presiding officer. ${ }^{45}$

In his message to the Eighth General Assembly (1860), retiring Republican Governor Ralph P. Lowe reviewed the history of common school reform and concluded that the new school system was operating with reasonable success. He acknowledged that objections had been made but believed that these had been rectified in recent board amendments to the law.

44. Cook, Baptism of Fire, 114-15; Morton M. Rosenberg, lowa on the Eve of the Civil War: A Decade of Frontier Politics (Norman, OK, 1972), 196; Frank J. Stork and Cynthia A. Clingan, The Iowa General Assembly: Our Legislative Heritage, 1846-1980 (Des Moines, 1980), 5.

45. Aurner, History of Education in Iowa 1:62, 64, 254-55, 2:34-35, 123; Secretary, State Board of Education, Report, in Leg Doc, 1859, 6, 22. 
Lowe hoped that the General Assembly would not make major changes in the amended law. ${ }^{46}$

Governor Lowe did well to hope because change was in the air. The General Assembly received many petitions and resolutions requesting revisions of the 1858 School Law. These included requests to abolish the board of education, the office of county superintendent, and the township district. These requests raised the constitutional question of whether the General Assembly had the power to enact such legislation. The matter was referred to the House Judiciary Committee, which recommended that the General Assembly abolish township districts and establish independent districts subject to approval by the board of education at its next meeting in December 1861. The Committee on Schools, established by the House to draft a bill for an independent district system, submitted three bills prepared by the secretary of the board of education. They provided for (1) the collection of taxes assessed by the subdistrict (HF 358); (2) the abolition of the township district and institution of the independent district (HF 356); and (3) a board of education meeting in December 1860, a year earlier than scheduled (HF $357){ }^{47}$

Assessment of taxes by subdistricts (HF 358) was the least controversial measure. It passed the House by a vote of 64 to 4 and the Senate by a vote of 24 to 7 , with all but one of the nay votes in both houses coming from Democrats. Abolition of the township district and the institution of independent districts (HF 356) was a more controversial change. It passed the House by a vote of 58 yeas (25 Republicans and 29 Democrats) to 21 nays (20 Republicans and 1 Democrat). Republican Benjamin Gue offered an amendment to "provide for education of colored youth in separate schools when provided by a majority of legal voters in each district," which lost by a vote of 32 yeas (including 1 Democrat) to 48 nays (14 Republicans and 32 Democrats). The bill was indefinitely postponed in the Senate without a roll call. Although the Senate did not concur in establishing independent districts, it acceded to local sentiment by approving HF 88, an

46. "Message of Governor Lowe," 1860 lowa Senate Journal, 18-20.

47. 1860 lowa House Journal, 73, 82, 104, 132-33, 149, 188, 235, 255, 455, 547-48. 
act allowing unincorporated towns with at least three hundred people to establish independent districts. ${ }^{48}$

These votes demonstrate that the Democratic Party favored more local control in education and opposed establishing even segregated schools for African Americans. Republicans were more divided on the issue of race. Some were willing to compromise on segregated schools if they could establish the principle that black children were entitled to a public education. Others insisted that black children were entitled to attend the same common schools as white children. Similarly, many Republicans were willing to compromise on the principle of a more centralized public school system in face of popular demands for more local control, while others were unwilling to grant local control to the extent implied in the effort to allow independent districts.

Whatever educators wanted and whatever common school reformers intended when they enacted the Mann Commission recommendations for a more unified system of public education, the centralized institutions created by the Constitution of 1857 and the School Law of 1858 were steadily dismantled beginning in 1860 , because Iowa farmers and townspeople preferred local neighborhood control of their schools. The board of education survived the battle in 1860, but its days were numbered. County superintendents survived, but lost their power to visit the schools. Township districts survived, but subdistricts were given the power to tax and the power to elect township district board members.

Responses to the 1860 reforms were predictably mixed. The Democratic Fayette County Pioneer was disappointed that the changes had not granted even more local control. The Re-

48. Stork and Clingan, Iowa General Assembly, 50-97, 109-211; 1860 Iowa House Journal, 270, 547-48, 573, 587-89, 656; 1860 Iowa Senate Journal, 312, 639-40, 718-21; Aurner, History of Education in Iowa, 1:63. According to the 1860 lowa Senate Journal, 312, the Senate passed HF 88, but I have not found a record of the vote. The House passed HF 88 by a vote of 55 yeas (38 Republicans, 16 Democrats) to 22 nays (5 Republicans, 16 Democrats) with 8 absent or not voting (4 Republicans, 4 Democrats). 1860 lowa House Journal, 270. It is difficult to explain why the Democrats divided evenly on this decentralizing measure. Discrepancies in the numbers are due to inconsistencies in the recorded roll calls and to the unknown party affiliations of two members. 
publican Fairfield Ledger hoped that giving more power to subdistricts would end the chronic criticisms of the 1858 School Law. Professional educators tended to stand by the original recommendations of the Mann Commission. At the 1860 meeting of the ISTA, educators recommended that the full powers of the county superintendent be restored and that the board of education be continued. ${ }^{49}$

Both recommendations encountered popular resistance. With the failure of the independent district bill, the board of education did not need to meet in 1860 to ratify the change. Instead, the General Assembly passed a bill which in effect abolished the board by postponing its meeting date until after 1863 , when it could be constitutionally eliminated by the General Assembly. This action provoked much press comment. The Iowa Democratic Enquirer (Muscatine) had already called for the abolition of "this fifth wheel." Republican papers did not oppose abolition of what they considered a Democratic invention. The Tipton Advertiser reported that the board had done its work so well that it did not need to meet. Regardless of press sentiment in favor of abolishing the board, Republican Governor Samuel Kirkwood vetoed the bill, arguing that it conflicted with the spirit of the constitution and that abolition would create confusion. Kirkwood's veto only postponed the inevitable. The General Assembly abolished the board of education in 1864. At that time, Republican Governor William Stone announced that the board was no longer required because it had created "the framework of our present admirable system of common schools." The General Assembly, unhappy that the board's authority overlapped its own, agreed with the governor and reestablished the office of state superintendent of public instruction. ${ }^{50}$

49. Fayette County Pioneer (West Union), 19 and 26 December 1859 and 27 February 1860; Fairfield Ledger, 17 February 1860; "Meeting of the ISTA," Iowa Instructor 1 (September 1860), 378-79, 384-85.

50. Aurner, History of Education in lowa, 2:124; Iowa Democratic Enquirer (Muscatine), 22 December 1859; Tipton Advertiser, 2 February and 15 March 1860; Fairfield Ledger, 3 February and 2 March 1860; Iowa City Weekly Republican, 15 March 1860; "Inaugural Address of Governor Stone," in Leg Doc, 1864, 4-5; Swisher, "Century of School Legislation," 180. 
Democratic decentralization continued after 1864. An 1872 law permitted the foundation of independent rural districts if desired by a majority of voters in the township. The collapse of the township district system and the rapid expansion of independent districts quickly followed. In responding to these local demands, Iowa legislators followed the pattern of Massachusetts and other states, where similar attempts at centralization also were met by demands for unrestricted local control. ${ }^{51}$

DESPITE THE WEAKENING of the centralizing, bureaucratic, and supervisory proposals of the Mann Commission Report and the 1858 School Law, Iowa common school reformers had attained many of their objectives. As in many western states at that time, Iowa common schools became fully tax-supported and free for all children. Legal requirements for establishing schools by local communities were clearly stated. The quality of teachers and teaching could be improved at regular teachers' institutes. More children attended common schools. In 1863, 71 percent of Iowa's 281,733 school-age children were enrolled, and 39.5 percent attended regularly. Although these numbers were lower than reformers desired, they were significantly higher than the 42.4 percent enrolled and 24.5 percent attending regularly a decade earlier. ${ }^{52}$

Given the success of democratic decentralizers in dismantling the township district system, it is important to ask why the recommendations of the Mann Commission Report were ever enacted in Iowa. The rapid development of commercial agriculture and towns and the rapid integration of the state into a national market economy led the political and educational leaders of the rural and urban middle class to demand, as they did in other states, the expansion of public schooling. Iowa common school reformers appealed to the ideology of common

51. Aurner, History of Education in Iowa, 1:72-77, 254-59, 264-66; Butts and Cremin, History of Education, 255-57.

52. Free schools were established in Wisconsin (1848), Indiana (1852), Ohio (1853), Illinois (1855), and Michigan (1869). Butts and Cremin, History of Education, 252. For attendance, see Supt. P.I. Report, in 1855 Iowa Senate Journal, 137-39; and Secretary, Board of Education, Report, in Leg Doc, 1864, 7-8. 
school reform, which they promised would school all classes in a middle-class culture of character and self-improvement. The emergence of the Republican Party in the 1850s gave reformers the opportunity to legislate a new system of free schools. Commercial development, the Republican Party, and common school reform came together in 1856 when Whig-turned-Republican Governor James W. Grimes appointed Horace Mann, architect of the Massachusetts system of public schools, to head a school commission. $^{53}$

The recommendations of the Mann Commission were enacted in the 1858 School Law because the Republican Party controlled the state house and the General Assembly. Some Democrats joined the Republican majority in supporting the law because all shared middle-class cultural allegiances to the republican, capitalist, and Protestant values of the ideology of common school reform. They recognized the need for common schools as a necessary internal improvement for a developing state. The state and local communities needed schools to promote their development and attract immigrants. Individuals similarly needed to be inculcated with the values of the Protestant ethic in order to make their way in the new capitalist economy and yet preserve republican institutions. ${ }^{54}$

That Iowa schools were quickly decentralized and often languished for lack of funding is due to the unresolved contradiction in the middle-class culture that created systems of common schools. Neighborhoods and individual taxpayers were often torn between the educational benefits promised by higher funding and centralized control and the individual desires for lower taxes and local control. All was not lost by these developments, however. Public schools founded by independent districts, as required by state law and supervised by state and county officials, promoted the development of rural communities and often educated rural children in the republican, capitalist, and

53. Sellers, Market Revolution, 364-69.

54. Butchart, "Education and Culture," 354-57, 361-65; David Tyack and Thomas James, "State Government and American Public Education: Exploring the 'Primeval Forest," History of Education Quarterly 26 (1986), 42-49; John G. Richardson, "Town versus Countryside and Systems of Common Schooling," Social Science History 11 (1987), 415-16, 422. 
Protestant values articulated by the ideology of common school reform. ${ }^{55}$ Children were thus equipped to leave the farm and the state and make their way in the growing urban-industrial society of the United States. If they remained on the farm and in the state, they were similarly trained to be morally responsible and productive citizens of a state founded on commercial agriculture and integrated into a national market.

55. Butchart, "Education and Culture," 263-64; Wayne E. Fuller, "School District 37: Prairie Community," Western Historical Quarterly 12 (1981), 427-31. 
Copyright of Annals of Iowa is the property of State of Iowa, by \& through the State Historical Society of Iowa and its content may not be copied or emailed to multiple sites or posted to a listserv without the copyright holder's express written permission. However, users may print, download, or email articles for individual use. 